\title{
Investment in Space Resources: Property Rights to Natural Resources Extracted in Space and the Position of Iraqi legal system
}

\author{
"Analytical study"
}

\author{
Arez Mohammed Sediq Othman \\ College of Law, University of Sulaymaniyah, Sulaymaniyah, Kurdistan, Iraq
}

\begin{abstract}
In the second half of the last century, the space activities have increased paralleled with the rapid development in space technology. The greed of giant corporations has exceeded the universe and tried to reach resources outside Earth. Exploring other planets is not something new, while racing to reach the resources outside earth by private space exploration companies as human's off earth destiny is quite recent. Many nations have plan to reach the moon by 2020 including the United States who has plan to establish a permanent base on moon by 2024 . The ambition to reach outer space is not just for the scientific purposes, but rather to exploit resources form space. As long as space is a common sphere among all the nations, there are many treaties signed and ratified to lay down broad rules and principle to organize the area. Mining celestial materials is one of the issues that does not have a legal framework as private companies are eagerly trying to mine materials which are not existed on earth such as Helium three or any other bodies that are scarce on earth. Until now, the international community has not been successful in establishing a solid legal system to regulate outer space activities. Besides, there are attempts by some countries to have particular legislation allowing private companies to extract natural resources. However, technological, economic and military powers of countries are the major factors in exercising the activities outside our planet due to the special nature of such activities. This paper argues that despite the difficulties of having a consensus over a legal framework, there are many other issues that need to be taken into consideration. Further, the perspective of the Iraqi legal system is also examined with regard to the possibility of adopting particular law on outer space activities. It also argues that although the lack of advanced technological skills might avoid countries reaching outer space, it will not prevent states from adopting specific legislation to regulate private corporations' attempt to explore in this field.
\end{abstract}

Index Terms-Space Resource, Outer Space, Property Rights, Space Act, Ownership, Moon Agreement, Outer Space Treaty, Investment, Luxembourg Space Law, USA Space Law.

\section{INTRODUCTION}

The burgeoning population on earth in the twentieth century and the increased demand on fossil fuel have created a desperate need to search for alternative sources of energy. Besides, the huge rare raw materials of different minerals on other planet, especially on moon, have fostered private corporation to plan exploration (Ram S. Jakhu and others, 2017, p. 138-143). These materials are quite rare on earth or even non-existent including Helium 3, isotope, platinum and nickel. This means that there is an overwhelming demand to exploit the natural resources on outer space to provide a substitute energy; for such activities, there should be a legal framework to provide a legitimate basis. Some countries such as United states of America and Luxemburg initiated to enact a specific legislation to regulate outer space activities with regard to extract natural resources. For instance, The USA has adopted Spurring Private Aerospace Competitiveness and Entrepreneurship (SPACE) Act of 2015 which permits the US citizens to engage in exploitation and exploration of space resources (Report of The Commission of Economy Preceding the Law, 2017, p.2). Further, Luxemburg has also issued the Act on the Exploration and Use of Space Resources (the Space Resources Act) in 2017 that allows the ownership of space resources (Article 1 of Space Resource Act). Within the scope of space mining legislations, Luxemburg has taken a more lenient position toward private companies in exploiting natural resources. It has significant differences to that of the US's Space Resources Act. The US law requires corporations to have more than $50 \%$ of US-backed equity, while Luxembourg does not set such limitations (Justin Calderon, 2018). Moreover, when it comes to international law, the relevant treaties are reluctant in providing comprehensive and clear rules to regulate all aspects of such area, particularly with regard to the exploration of natural resources. In this

Journal of University of Human Development

Volume 5 No. 1(2019); DOI: 10.21928/juhd.v5n1y2019.pp36-43

Regular research paper: Received 1 December 2018; Accepted 24 December 2018; Published 21 January 2019

Corresponding author's e-mail: arez.sediq@univsul.edu.iq

Copyright (C2019 Arez Mohammed Sediq Othman. This is an open access article distributed under the Creative Commons Attribution

License (CC BY-NC-ND 4.0) 
regard, the United Nation Office for Outer Space Affairs (UNOOSA) is the only international agency under the supervision of the United Nation to develop international space laws which was created in 1958. The most prominent international treaties in exploiting natural resources of outer space field that can provide legal framework for outer space activities are the Outer Space Treaty 1967 (Treaty on Principles Governing the Activities of States in the Exploration and Use of Outer Space, including the Moon and Other Celestial Bodies) and the Agreement Governing the Activities of States on the Moon and Other Celestial Bodies also known as Moon Agreement 1979 (Sarah Coffey, 2009, p.125-127). Iraq has only ratified the Outer Space Treaty without taking any action to enact any law related to outer space. It can be said that Investment in outer space is a multi-dimensional issue pushing countries to take advantage from every aspect of it such as technology, science, economy, military and so on. Talking about economy, the role of outer space resources in boosting economy has been pointed out by many. For instance, Luxemburg's ministry of economy indicated that space industry accounts for some $1.8 \%$ of the nation's GDP, the highest ratio of any EU country. He insisted that Luxemburg's Space Resources Act opened a sluicegate for investment in the country by attracting foreign investors and giant space companies to invest in the field (Justin Calderon, 2018).

\section{Research objectives}

Outer space industry has developed very quickly in the recent years, giant space companies have raced to exploit other planets and extract natural resources. However, there is not a clear image for the international community to conduct their activities outside our planet. There are few researches conducted in this field to create a legal foundation of state activities. Moreover, this is the first time a research will be conducted indicating the legal status of Iraq within the context of outer space industry and to investigate whether Iraq has any groundwork to join international community in seeking its share from natural resources that will be extracted from other planets. The main objective of this research is to indicate the legal attempts to establish the legal framework of state activities in the outer space.

\section{Research problems}

Due to the common nature of outer space, international community has tried to establish a legal framework for the activities outside earth. Under both national and international laws, there were attempts to regulate such activities through international conventions and the enactment of particular law in outer space field. The USA and Luxemburg are leading in this area as they have outer space legislation. The recentness of the industry and the lack of proper legal basis for states' activities have left international community powerless to a unified set of legal tools for their activities outside earth. The extraction of natural resource in the outer space will play an important role in securing the future of states on earth as it is rich with scare resources. Furthermore, the lack of particular legislation in Iraq on outer space will leave Iraq behind developed countries. Thus, this paper will shed light on the legal issues with regard to the extraction of natural resources by states.

\section{Research methodology}

An analytical approach has been adopted in conducting this paper. The paper has relied on all the relevant regulation on both national and international levels to analyse the legal basis of outer space activities by different countries with taking examples of different legal systems who has initiated on adopting outer space legislation such as USA and Luxemburg.

\section{Research outlines}

This paper is divided into five sections. Section one is the introduction in which the area is introduced, research objectives stated, research problems discussed with indicating methodology which has been adopted in conducting the research. Section two provides the overview of natural resources on the outer space. Section three discuss Sovereignty and ownership over outer space resources. Section four then deals with Iraqi Law position. The final section has been dedicated to conclusion and recommendations.

\section{NATURAL RESOURCES ON THE OUTER SPACE}

Peaceful exploration and uses of outer space have been emphasized many times by the United Nation General Assembly. The Committee on the Peaceful Uses of Outer Space, in its forty fourth session in 2001, has indicated that "...beneficial uses of space such as strengthening communications infrastructure, disaster management, education, agriculture, environmental protection and natural resource management had enormous relevance for human development..." (Report of the Committee on the Peaceful Uses of Outer Space, 2001). Further, article 4 of the Outer Space Treaty has prohibited the use of the outer space to nuclear exercises or any other weapons of mass destruction by the member states and the peaceful use of all the celestial bodies. Thus, the use of the outer space for the peaceful purposes is mandatory for all the states and it should be utilized in a manner consistence with "the interest of maintaining international peace and security and promoting international cooperation and understanding" (Article 3 of the Outer Space Treaty). Therefore, it can be said that there is a consensus among international community not to use outer space for military purposes under any circumstances. Meanwhile, there is a great expectation to the natural resource available on the outer space as a source of sustainable energy. Many economists and entrepreneurs including Peter Diamandis, vice chairman of Space Adventures Corporation, have expected that the future supply of earth can be relied on extra-terrestrial economy. He is also insisted on decreasing the cost of traveling to the outer space and the rapid development in the space technology which facilitated the work of both governmental institution and private corporations in exploring outer spaces (Peter Diamandis, 2012). Concerning the meaning of natural resources, the United States 
of American, as a first country that has regulated space activity within the context of domestic law in 2015, has defined space resources as "an abiotic resource in situ in outer space" including minerals and water excluding biological life (Section $202 \S 51301$ (2) of the USA SPACE Act 2015). Further, some scholars believe that natural resources do not only limited in raw materials and minerals. For instance, Iraqi representative at the General Assembly insisted on using the outer space resources for disaster planning by stating that "Iraq had also been using outer space resources for disaster planning and learning the causes of disaster, especially concerning the potential collapse of the Mosul dam and potential flood areas. From the information gained, Iraq had set up a website as an early warning system to provide immediate information and aid should such an event occur" (Securing Sustainability of Outer Space Technology as Significant Contribution to Modern Societies Meant Guarding against Militarization, Deterioration, 2013). Furthermore, Mohammed Huseein Bahr Aluloom, Permanent Representative of Iraq to the United Nations in New York and the Chair the First Committee (Disarmament and International Security), has mentioned the significant of advancing space activities for socioeconomic development (concluding General Debate on Peaceful Uses of Outer Space, Fourth Committee Approves 3 Draft Resolution, 1 Decision, 2017) On the other hand, investment in outer space areas does not limited in only in the extraction of natural resources or valuable materials, there is a huge tourism potential in the outer place. Since the successful journey of SpaceShipOne in 2004 and the increasing attention to build space vehicles, there are legal questions around liability and the legal status of tourists in the outer space similar to the uncertainty with regard to the legal basis for extracting natural resources on another planet. The lack of an established international legal regime and the common asset nature of outer space have complicated investment. Due to the significance of exploring outer space, many countries are trying to expand their commercial activities cover outer space celestial bodies. For instance, the United Arab of Emirate is in the process of regulating space law similar to USA and Luxemburg UAE Space Agency director general Mohammed Al Ahbabi stated "The year 2021 will be the 50th anniversary for the UAE, so it is an appropriate deadline that the first UAE space mission should happen by this time" (Lucy Barnard 2016, the National Business Report).

Until now, the only area which is developed quickly is telecommunication. It has reserved a main place in commercial space market as several satellite operators have earned record revenues since 2008 despite the economic crisis. The main earnings are coming from satellite television broadcasting and a robust demand from institutional users (defence, new customers in the developing world, development of anchor contracts). The lease of transponders and communications via satellite represented some USD 11-15 billion in revenues, and satellite broadcasting (e.g. television via satellite) some USD 65-72 billion in 2009 (The Space Economy at a Glance, 2011). This area has seen a great development and it is well organized among the relevant corporations and states as the framework of the work is more obvious that other areas such as commercial use of the resources or any other celestial bodies outside our planet due to the common nature of the materials and the tangibility of the resources. Moreover, there is a huge demand by many countries to use satellite information. In the past two decades, satellite information has been used for combating terrorists around the world and there is a growing demand by countries to use such resources. For instance, both Egypt and Syria have proposed to utilize satellite technology to combat terror acts at the Committee on the Peaceful Uses of Outer Space at the United Nations. The proposal was a draft of a paper under the name of "Combating Terrorism using Space Technology" to presented by Egypt to the Committee in 2017. The Egyptian delegation indicated that, "Delays in adding this item may affect the lives of a number of new innocents" (Egypt and Syria Propose Using Satellites to Counter Terrorism at UN Space Meeting, 2017). This has put an ethical burden on countries who are leaders in the space. As Monica Konrad has singled out "...the ethical status of the astronaut cannot be divorced from the space industry, the work of national and international space agencies, space consultancy contractors and space engineers. Nor can it be separated from various publics such as non-scientific space consumers, or the role education and the media play in shaping and transforming public responses to and expectations of new future worlds" (Monica Konrad, 2004, p.32). In the following section, the issue of ownership of the extracted natural resources in the outer space will be examined.

\section{SOVEREIGNTY AND OWNERSHIP OVER OUTER SPACE RESOURCES}

As long as outer space is considered to be common assets to the whole universe, international community has to have agreed upon a bunch of legal rules and principles in this field; it is developed as a direct body of international law. In terms of regulating the aspects of outer space, there is a considerable form of domestic and international principles to deal with the exploration of outer space resources, including multilateral treaties, UN resolutions, decisions of the domestic courts and attentions by intergovernmental organizations (Steven Freeland, 2005, p.4-5). Under the international law, there are five main treaties that regulate the activities of the outer space field, namely: Treaty on Principles Governing the Activities of States in the Exploration and Use of Outer Space, including the Moon and other Celestial Bodies ("Outer Space Treaty"); Agreement on the Rescue of Astronauts, the Return of Astronauts and then Return of Objects Launched into Outer Space ("Rescue Agreement"); Convention on International Liability for Damage Caused by Space Objects ("Liability Convention"); Convention on Registration of Objects Launched into Outer Space ("Registration Agreement"); Agreement Governing the Activities of States on the Moon and other Celestial Bodies ("Moon Agreement"). However, as Freeland has indicated, nearly all of the treaties were formed during the cold war era when space capacity of the countries was limited and they did not have potential to develop a comprehensive set 
of rules. Besides, the polarizing powers had influence on the membership of the conventions (Steven Freeland, 2005, p.4-5). Furthermore, the signatories of the treaties have not reached a substantial point when it can be considered as multilateral treaties that create a source of enforcement for non-state parties. For example, Moon Agreement has only 18 parties without the membership of super powers such as USA or Russia. Nonetheless, the existence of such treaties played a significant role in setting basic principles when many countries agreed upon certain issues. For instance, despite the flaws and incomprehensive nature of the international conventions in this field, it could gather states on some baselines that could be developed later such as Outer Space Treaty which has 107 state parties including the five permanent members of the UN Security Council with 23 signatories who do not ratified it yet. Article 1 of the treaty gives the right to all countries to conduct exploitation without any discrimination by stating that "Outer space, including the moon and other celestial bodies, shall be free for exploration and use by all states without discrimination of any kind, on a basis of equality and in accordance with international law, and there shall be free access to all areas of celestial bodies." None of the states have right to claim power or sovereignty over the moon or any other celestial bodies (Article 2 of the Outer Space Treaty ); this indicates equalities between all the states when it comes to extracting natural resources.

The provisions of the Outer Space Treaty are quite debateable and vague when it regulated the activities of states over outer space as it articulated that "the exploration and use of outer space, including the moon and other celestial bodies, shall be carried out for the benefit and in the interests of all countries, irrespective of their degree of economic or scientific development" (Article 1 of the Outer Space Treaty). By looking at the content of the article, it can be realized that it is more look like a guideline to foster the sharing of resources and knowledge to other less developed countries with the lack of having a crestal clear method of that sharing. With regard to the moon agreement, the main reason behind the rejection of the content of the agreement is that the property rights are prohibited and the resources over the celestial bodies was considered a common heritage of all human being. Further, the agreement established a merely impossible mechanisms for the process of extracting natural resources and called for the distribution of the raw materials derived from space which led to be unattractive for the countries that have a developed space program and do not want to share their business profit with other nation that do not own space program. Moreover, despite having some treaties to regulate the outer space activities, the remaining question is that to what extend the international law is enforceable by the nations. International law, unlike domestic law cannot be enforced immediately and its implementation is rather controversial due to the lack of enforcement mechanisms.

However, the knowhow and technical skills of countries can be taken into consideration when it comes to exploiting natural resources in the outer space. Although it is difficult to draw analogy, the sovereignty of states over natural resources inside their territory is similar to the capability of states to reach the outer space and explore natural resources as it is a sign of extending their sovereignty while other countries cannot. The UN General Assembly Resolution, Permanent Sovereignty over Natural Resources states 'The right of peoples and nations to permanent sovereignty over their natural wealth and resources must be exercised in the interest of their national development and of the well-being of the people of the State concerned.' (Article 1 of the UN General Assembly Resolution, Permanent Sovereignty over Natural Resources). This is more a realistic approach due to the discrepancy among the power of states under international community; countries with advanced technology will spent more resource and manpower to exploit natural resources than the less developed countries. According to the UN Charter, countries are equal in rights and duties but this does not mean to share the gaining. In addition, countries like the USA and Russia that are advanced in space program have also responsibility to protect earth from any natural disaster caused by other planet. Additionally, to some extend there are other boundaries and restriction to the extraction of natural resources in other planet such as the transportation capacity as it has been emphasized by Barry Kellman, law professor at De-Paul University, Chicago, indicating that regulations are not the only limitation so much as the costs of extracting resources and transporting them: "How you bring a ship full of rocks back to Earth and do it very safely, that's the major challenge." (Aliya Ram, Financial Times, 2017).

On the other hand, some scholars would do analogy to make an independent system for mining in other planets by comparing the resources in the outer space to the one in the oceans and poles as the latter have areas where none of the states have control over them. By looking at the law of the sea, the United Nations Convention on the Law of the Sea (UNCLOS) have resolved the ownership of the resources that will be found on the international seas. For instance, similar to the provision in space conventions (Outer Space Treaty and Moon Agreement), the UNCLOS has stated that "The area and its resources are the common heritage of mankind" (Article 136 of UNCLOS). It also established what is known as International Seabed Authority to control all the activities related to the extraction of natural resources. This, to some extent, meaning that there is a sort of consensus among the member state to regulate their activities in this regard. However, the problems related to lunar mining is more or less exist to exploring international seas as the political and economic powers of states are different and international law is not the only safeguard to reach equality among the nations. Moreover, exact analogy cannot be done in this regard as the authority of states on earth is much more attainable than their capacity over other planet meaning that the work over the resources of international sea is more feasible than on outer spaces. Further, some scholars such as Hugo Grotius, does not agree with the concept of ownership of the sea by the states, he states that oceans do not belong to any states and they cannot claim sovereignty over international waters (Hedley Bull, 2012, p.306-308). In addition, Gabrielle Leterre in his thesis on 'providing a legal framework for the sustainable space mining activities' reach a conclusion by indicating that: 
"...the difference between the oceans and outer space on one hand, and between sea resources and space resources on the other hand is too great to allow a transposition of the regime to outer space" (Gabrielle Leterre, 2017, p.59). The issues with regard to ataractics is very similar to international sea, the analogy is not reasonable as it claimed by some scholars. Concerning the applicable law, Lafferranderie states that space law compromises all national and international legal rules and principles governing the exploration of outer space by states, international organizations, private persons, companies and all other relevant actors in this regard (Gabriel Lafferranderie, 1997, p.29). However, the inconsistency between the national and international legislations is problematic when it comes to having a comprehensive legal basis to space activities. Philip De Man has emphasized the fact that any legislation gives permission to private actors to appropriate natural resources from other planet for business purposes, it will raise a question of consistency with articles one and two of Outer Space Treaty which requires equal interest of all states in mining over celestial bodies (Philip De Man, 2017, Newspaper Article from The Space Review). This will ban national ownership of the resources extracted from other planets. In the following section, the status of Iraqi legal system will be analyzed in relation to outer space field.

\section{OUTER SPACE AND THE IRAQI LEGAL SYSTEM}

Under the Iraqi legal system, property rights have been adopted for individuals over any kinds of properties; according to the Iraqi Civil Code of 1951, everything is subject to ownership except those things which are by their nature or by law excluded from ownership (Article 61(1) of the Iraqi Civil Code No.40 of 1951). Property is defined as everything having a material value (Article 65 of the Iraqi Civil Code No.40 of 1951). The Iraqi Civil Code recognizes the right to complete private ownership of property by individuals or legal entities. In the Iraqi legal system, the owner of the property is considered to be the owner of everything commonly considered to be an essential element of it (Article 1049 of the Iraqi Civil Code No.40 of 1951). Constitutional-wise, the Iraqi Constitution also reflects this balance between the needs of the state and incentives for individuals. Article 16 states that:

a) Ownership is a social function, to be exercised within the objectives of the society and the plans of the state, according to stipulations of the law.

b) Private ownership and economic individual liberty are guaranteed according to the law, and on the basis of not exercising them in a manner incompatible with the economic and general planning.

c) Private property is not expropriated except for considerations of public interest and for just compensation in accordance with the law.
According to the World Resources Institute in collaboration with United Nations Development Programme, the rights of the user in land and property can be classified as the followings:

- The right to use the resource;

- The right to profit from use of the resource;

- The right to sell one's tenure rights to others, permanently or for a limited time;

- The right to pass down these rights to one's successors;

- The right to protection from illegal expropriation of the resource (World Resources Institute, 2005).

These articles cannot be applied on natural resources owned by private companies on the outer space as this is property rights for owning properties within the Iraqi border. Moreover, in Iraq, government and related ministries have right to own public lands and natural resources as it happens in oil and gas industry. For example, In the Kurdistan region, Oil and Gas law of 2007 has stated that "Petroleum in the Region is owned in a manner consistent with Article 111 of the Federal Constitution. The Regional Government is entitled to a share from the revenues from producing fields, consistent with the share of all Iraqi people, in accordance with this law and Article 112 of the Federal Constitution." (Article 3 of the KRG Oil and Gas Law No.28 of 2007). Further, the Iraqi Civil Code in articles 1099, 1100 and 1105 allowing absolute ownership of properties and water on the condition they do not cause harm to others.

Now, the practical question is that does Iraq has skills and knowhow to explore space? As it can be clarified from the above-mentioned statements, the Iraqi regulation exclude all the materials that cannot be owned or reached. Thus, Iraq or any other developing country has to have an argument to ask for the share of the materials that will be extracted by the developed countries as the "common heritage" or "sharing of the benefits" have been emphasized in many international space treaties. Nevertheless, seeking such shares is not an easy task for a country like Iraq which is in a very weak position.

Within the Iraq territory, despite owning the big portion of land by the government, the government has right to expropriate any properties for the purposes of public benefit based on some legal requirement which has determined under the Acquisition Law No.12 of 1981. The process will take place through Judicial Expropriation when any state department may become the owner of a privately-owned plot of land or a property via a Civil Court decision. To expropriate a specific plot of land or property, the court is legally responsible for proving that no objection to the transfer exists. Further, it might take the shape of administrative expropriation when the real estate ownership is transferred from one governmental body to another. The amount of money exchanged is agreed upon either through the ministers, or sometimes through the prime minister if the transfer is between two different ministries. Thus, the government has a wide power over all the properties and lands within the boundaries of Iraq. However, this authority cannot be extended to natural resources in the outer space. Therefore, it can be said that despite the fact that Iraq has recognizes the 
importance of this matter, it has not conducted any attempt to work in this area (Committee on the Peaceful Uses of Outer Space, Legal Subcommittee in their Forty ninth session 22 March - 1 April 2010), unlike the USA and Luxemburg.

\section{LUXEMBURG AND USA, INVESTMENT IN OUTER SPACE}

Due to the legal restriction from international law in recognizing property rights over moon or other celestial bodies by any nations, some countries such as the US and Luxemburg have resorted to issue mining law to allow private companies to appropriate materials. As it has been discussed before, both USA and Luxemburg are considered to be leading countries when it comes to investment in outer space. In other word, the two countries have initiated to enact national legislation to regulate mining activities and private ownership to resources on celestial bodies. United States was the first country to adopt a national regulatory framework for space mining activities when they issued "Space Resource Exploration and Utilization Act" in 2005. In the purpose of the law, it states that "The purpose of H.R. 1508, the "Space Resource Exploration and Utilization Act of 2015," is to establish a legal framework to govern property rights of resources obtained from asteroids enabling this new industry and providing clarity for future entrepreneurs." This statement is very close to what has been pointed out by Etienne Schneider, Luxembourg's Deputy Prime Minister and Minister of the Economy, he states "Our goal is to put into place an overall framework for the exploration and commercial use of resources from 'celestial bodies' such as asteroids, or from the moon." (Andrew Zaleski, 2018, CNBC newspaper article). Therefore, it can be said that the main goal behind having a domestic legislation is to legitimize all the activities conducted by the countries and allowing private ownership to space resources by private corporations. These cannot be fulfilled without having a legal framework inside the state. Moreover, Luxemburg's space act will provide more elastic sphere for international companies to invest. For example,

The USA's law requires companies to have more than $50 \%$ of US-backed equity, while Luxembourg sees no such restriction (Justin Calderon, 2018). Nonetheless, the legality of their attempt is questioned under the applicable international conventions. In this quest, they bring the argument that international conventions have prevented national appropriation by state not private ownership. For instance, Gorove indicated that Outer Space Treaty 'appears to contain no prohibition regarding individual appropriation' (Gorove S, 1968, p.42). However, many scholars believe that if it prohibited for states to appropriate resources, its nationals also banned to own properties over resources in the outer space. In this regard, Cheng stated that outer space, similar to high seas, will not belong to any states nor to their nationals (Bin Cheng, 1991, p.22). Hence, it can be realized that even these two countries do not have legal framework to be relied on when it comes to have domestic legislation to regulate outer space activities. There is a question of hierarchy of international law and internal law; can we have a domestic legislation allowing some activities of international nature without having international law support.

\section{CONCLUSION AND RECOMMENDATIONS}

Exploring outer space is not something new for many countries, in particular for the technological use. Many countries are competing to take the ultimate advantage of celestial bodies around earth. In the past ten years, exploring outer space for commercial purposes become priority for some countries, particularly when it comes to private appropriation of natural resources. United State of America and Luxemburg are considered to be leading countries in this regard by enacting domestic legislation to allow private corporation reaching outer space for business purposes. Under the international law, there is a lack of unified code to be agreed upon by international community. The absence of legal framework to support state mining activities has left states uncertain about the legality of such activities under international law. This has also raised a question on the national legislations issued by some states to reach outer space. Some scholars have made analogy between ownership of natural resources in the outer space and international waters or natural resources on the poles. Nonetheless, it can be realized that this analogy is not realistic as states have more lenient access to oceans or poles than other planets which led to have practical mechanism to agree upon the way they deal with natural resources on earth, oceans and poles. Moreover, having a legal system is not the only factor to be considered in mining natural resources in the outer space; even if states will be given equal opportunities, outer space is not reachable for many countries. The paper shed light on different aspects of mining industry on the outer space by indicating the perspective of both international and national laws. It explained the international treaties in this area such as Outer Space Treaty or moon agreement. It emphasized the fact despite in effective impact of the international tools in providing a legal basis of outer space treaties, it played a major role in introducing the main theme of space related activities, particularly the ownership of extracted natural resources. It also argued that less developed countries such as Iraq has a limited position in outer space industry and the only way Iraq could recently benefit from is satellite information to combating terrorist groups. Moreover, Iraq does not adopt legislation on outer space law. Furthermore, the applicable property right laws do not mention ownership of natural resource outside Iraq. When it comes to the membership of international conventions, Iraq has only ratified Outer Space Treaty which considered natural resources in the outer space as a common heritage of all mankind.

In order to cope with the current development in the outer space industry, Iraq shall coordinate with developed countries to take more benefit from their experience, in particular to enact a specific law attracting international space companies for 
private ownership over outer space resources similar to Luxemburg as the latter become the interest point for many space mining corporations despite of not having any space technology. Thus, it can be said that not possessing knowhow and modern technology might prevent the country to reach other planets, but it would not deprive them from having a specific act regulating outer space activities.

\section{REFERENCES}

\section{International convention and legislations}

Iraqi Civil Code No.40 of 1951

KRG Oil and Gas Law No.28 of 2007

USA Space Resource Exploration and Utilization Act 2015

Spurring Private Aerospace Competitiveness and

Entrepreneurship (SPACE) Act of 2015

Act on the Exploration and Use of Space Resources (the Space Resources Act) of 2017.

Agreement on the Rescue of Astronauts, the Return of Astronauts and then Return of Objects Launched into Outer Space 1967 ("Rescue Agreement")

Convention on International Liability for Damage Caused by Space Objects 1972 ("Liability Convention")

Convention on Registration of Objects Launched into Outer Space 1974 ("Registration Agreement")

Agreement Governing the Activities of States on the Moon and other Celestial Bodies 1979 ("Moon Agreement").

Treaty on Principles Governing the Activities of States in the Exploration and Use of Outer Space, including the Moon and other Celestial Bodies 1967 ("Outer Space Treaty")

Books

Ram S. Jakhu, Joseph N. Pelton, Yaw O.M. Nyampong, Space Mining and Its Regulation, (Springer, 2017).

Peter Diamandis, Abundance: The Future is Better than You Think, (2012) Free Press, New York.

Hedley Bull, The Law of the Sea, in THE ANARCHICAL SOCIETY: A STUDY OF ORDER IN WORLD POLITICS 306 (4 ed. 2012).

Gabriel Lafferranderie, (Outlook on Space Law over the next 30 Years, 1997).

\section{Journals}

Sarah Coffey, 'Establishing a Legal Framework for Property Rights to Natural Resources in Outer Space', Case Western Reserve Journal of International Law', Vol 41, issue 1, 2009.

Monica Konrad, Legal and Ethical Framework for Astronauts in Space Sojourns, 2004, UNESCO.

Steven Freeland, Up, Up and ... Back: The Emergence of Space Tourism and Its Impact on the International Law of Outer Space, Chicago Journal of International Law, Vol6, No1, 2005.
Gabrielle Leterre, 'providing a legal framework for the sustainable space mining activities' Master Thesis, Sept 2017.

Gorove S, 'Interpreting Article II of the Outer Space Treaty' (1968) 11 Proceedings of the Colloquium on the Law of Outer Space 40.

Bin Cheng, 'The Commercial Development of Space: The Need for New Treaties' (1991) 19(1) Journal of Space Law 17, 22.

Websites

www.bbc.com [http://www.bbc.com/future/story/20180716the-tiny-nation-leading-a-new-space-race]

www.unoosa.org[http://www.unoosa.org/pdf/gadocs/A_56_ 20E.pdf]

www.ft.com [https://www.ft.com/content/af15f0e4-707a11e7-93ff-99f383b09ff9]

www.un.org[https://www.un.org/press/en/2013/gaspd538. doc.htm]

www.reliefweb.int[https://reliefweb.int/report/world/conclu ding-general-debate-peaceful-uses-outer-space-fourthcommittee-approves-3-draft]

www.thenational.ae[https://www.thenational.ae/business/ua e-to-finalise-space-laws-soon-1.219966 ]

www.spacewatchme.com[https://spacewatchme.com/2016/0 7/egypt-syria-propose-using-satellites-counterterrorism-un-space-meeting/]

www.thespacereview.com[http://www.thespacereview.com/ article/3355/1]

www.cnbc.com[https://www.cnbc.com/2018/04/16/luxemb ourg-vies-to-become-the-silicon-valley-of-asteroidmining.html]

www.oecd.org[https://www.oecd.org/sti/futures/space/ 48301203.pdf ]

\section{Miscellaneous}

Report of the commission of economy preceding the Law of 20 July, 2017 on the Exploration and Use of Space Resources], Doc. parl. 7093/06, 2016-2017.

Report of the Committee on the Peaceful Uses of Outer Space, 2001, section 24 available at http://www.unoosa.org/pdf/gadocs/A_56_20E.pdf

Planetary Resources overview, available at http://www.planetaryresources.com/company/ overview/\#why-asteroids

The Space Economy at a Glance 2011, Directorate of Science, Technology and Industry available at https://www.oecd.org/sti/futures/space/48301203.pdf

UN General Assembly Resolution, Permanent Sovereignty over Natural Resources, 1803 (XVII) of 14 December 1962, available at: http://unispal.un.org/ UNISPAL.NSF/0/9D85892AC6D7287E85256368005 96092 
World Resources Institute in collaboration with United Nations Development Programme, United Nations

Environment Programme and World Bank, The Wealth

of the Poor - Managing Ecosystems to Fight Poverty.

WRI: Washington, DC, 2005. 